\title{
Factors Contributing to the 2005-Present, Rapid Rise in Lake Levels, Dominican Republic and Haiti (Hispaniola)
}

\author{
Vanshan D. Wright ${ }^{*}$, Matthew J. Hornbach¹, Cecilia Mchugh², Paul Mann ${ }^{3}$ \\ ${ }^{1}$ Roy Huffington Department of Earth Sciences, Southern Methodist University, Dallas, USA \\ ${ }^{2}$ School of Earth and Environmental Sciences, Queens College, Flushing, USA \\ ${ }^{3}$ Department of Earth and Atmospheric Sciences, University of Houston, Houston, USA \\ Email: vidwright@smu.edu
}

Received 29 July 2015; accepted 23 August 2015; published 26 August 2015

Copyright (C) 2015 by authors and Scientific Research Publishing Inc.

This work is licensed under the Creative Commons Attribution International License (CC BY). http://creativecommons.org/licenses/by/4.0/

(c) (i) Open Access

\section{Abstract}

Lakes Enriquillo and Azuei, the two largest lakes in Hispaniola and in the Caribbean, have risen 10 and $5 \mathrm{~m}$ respectively within the last 8 years. Higher lake levels have submerged towns, road systems, agricultural lands and utilities, and have threatened to submerge the major overland highway that connects the Dominican Republic and Haiti. In this study, we use CHIRP seismic data, satellite imagery, and regional meteorological data to quantify and assess controls on the recent lake level rises. Although data are limited, the analyses indicate that the lakes' water level changes may be attributed to a combination of increased rainfall and natural or man-made changes to the hydraulic connectivity of the various water bodies within the drainage basin. We show that a weak correlation exists between changes in Lake Enriquillo's and Azuei's water levels and precipitation rates (0.2 and 0.08 respectively, 1984-2012) and that both lakes experience periods of anti-correlation where, for example, water level drops at Lake Azuei ( $\sim 20$ masl) coincide with water level rises at Lake Enriquillo (41 mbsl). From these observations, we propose that the lakes experience intermittent periods of hydraulic connectivity along reactivated or newly developed stratigraphic-controlled sub-surface transport pathways. We also note that moderately small $(<M w 5)$ earthquakes along the large active fault system that extends through both lakes may promote or limit hydraulic conductivity on decadal or shorter time scales. The extents to which recent earthquakes have triggered changes in groundwater flow at this site remain unclear but represent an important topic of future research.

Keywords

Lake, Enriquillo, Flood, Etang Saumatre, Azuei, Climate, Caribbean, Hispaniola

\footnotetext{
${ }^{*}$ Corresponding author.
}

How to cite this paper: Wright, V.D., Hornbach, M.J., Mchugh, C. and Mann, P. (2015) Factors Contributing to the 2005Present, Rapid Rise in Lake Levels, Dominican Republic and Haiti (Hispaniola). Natural Resources, 6, 465-481. 


\section{Introduction}

Lakes Enriquillo and Azuei are located $\sim 5 \mathrm{~km}$ away from each other in Dominican Republic and Haiti respectively (Figure 1). The hypersaline Lake Enriquillo forms both the largest lake $\left(352 \mathrm{~km}^{2}\right)$ and the lowest point (41 mbsl) in the entire Caribbean region. Lake Azuei is a smaller $\left(137 \mathrm{~km}^{2}\right)$ fresh-water lake that lies $\sim 20 \mathrm{~m}$ above sea level (Figure 1). Together, they have a combined area of $489 \mathrm{~km}^{2}$ (in 2013) and are the two largest lakes in Hispaniola (which host the countries Dominican Republic and Haiti) and the Caribbean region.

Previous studies have shown that Lake Enriquillo has experienced prolonged (decadal to multi-decadal) periods of sustained lake level rises and drops [1] [2]. The most prolonged period of lake level rise in the historical record occurred between 1959 and 1968 when water levels rose from 45 to 35 mbsl [1]. Between 1969 and 2000, the lake level steadily declined to a mean elevation of $48 \mathrm{mbsl}$, allowing local inhabitants to construct towns at sub-sea level elevations as well as allowing them to clear areas of the former lake bed for agricultural and pastoral lands [1]. Since 2005, a steady rise in Lake Enriquillo's water level has led to a reversal in the previous trend. Specifically, within the past three years, rising waters have displaced 16 rural communities and 10,000 families plus livestock, and have flooded 1000 homes and submerged 46,500 acres of agricultural lands assessed at $\sim \$ 2.5$ million US dollars [3] [4].

A smaller rise on the steeper-sided Lake Azuei has led to the inundation of lakeside towns, markets, and administrative buildings. Rising water from the lake has also disrupted communication by flooding sections of the main overland highway that allows for transportation and trade between the two countries. Understanding the causes for the past and recent changes in water levels is critical for remediation and hazard management efforts in the Haiti-Dominican border region [3] [4].

Reconnaissance studies by past and current workers hypothesize that lake level changes are controlled by a combination of short-term meteorological and geological changes in the region [2] [5]. One study [2] uses normalized vegetation indices, combined with interpretation of Landsat images, to test if Lake Enriquillo is responding to weather and land use/cover changes (LULCs) in the region. Their analyses indicate that LULCs in the region are subtle and do not correlate well with lake level changes from year to year, thereby implying that LULCs have had minimal impacts on lake levels. Instead, their study concludes that Lake Enriquillo's abrupt rise is related in part to a recent increase in the frequency and magnitude of storms in the region. However, the authors note that their results are limited by the lack of bathymetric and evaporitic data (for the lake) from which they will have been able to better constrain the lake's precise level and volumetric change with time. Another

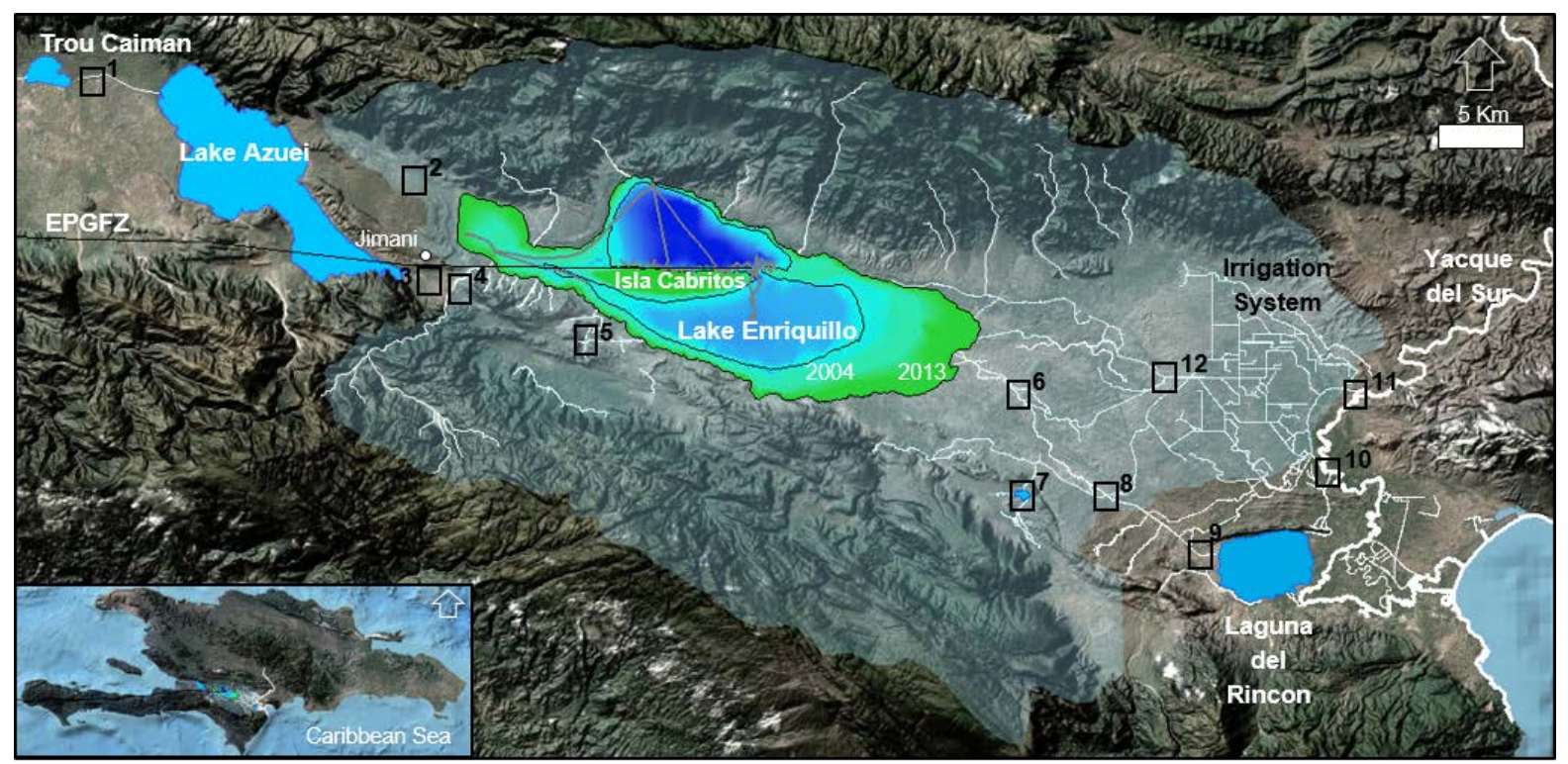

Figure 1. A map that focuses on Lake Enriquillo's drainage basin and the hydrologic connection between the water bodies within and outside of the basin. Water body locations that have undergone hydrologic changes since 2003 are boxed and numbered; white lines indicate streams or man-made channels; gray lines within the lakes are the seismic track lines. The map also shows the pattern of the lake's areal growth since 2004 and the location of the Enriquillo-Plantain Garden Fault zone (EPGFZ). Since 2004 the lake has grown significantly more easterly or westerly than northerly or southerly. 
study [5] documents several ongoing hypotheses that attempt to explain the relationship between lake level rise, and meteorological and geological changes in the region. Specifically, they document hypotheses that question if weather patterns, combined with either sea surface temperature anomalies or increases in sedimentation in the lake, are the causes of the recent lake level rise. Here we build on past studies [2] by analyzing new and necessary data that allow a re-assessment of the weather hypothesis.

Our main objective is to build on the previous studies, for example [2], by introducing geophysically-derived lake floor bathymetry maps, correlation analysis and empirically-derived estimates of evaporation rates that improve past assessments of the weather hypothesis. We also broaden the geologic background of Lake Enriquillo by not only analyzing its change in lake levels, but also including water level changes in the neighboring lake, Lake Azuei, which likely represents an important source of water for Lake Enriquillo (Figure 1). The analyses suggest that changes in hydraulic conductivity (between the lakes and surrounding regions) play an important role in lake level change. Because of this, we test a second hypothesis, henceforth defined as "the hydraulicconnectivity hypothesis". For this, we propose that changes in Lake Enriquillo's water levels are caused not only by changing weather patterns, but also by changes in surface and sub-surface hydraulic conductivity in the region. By re-assessing the weather hypothesis in light of the hydraulic connectivity hypothesis, our study proposes new and non-climatic controls which may be contributing to the recent rise in both lakes.

\section{Geologic Setting of the Enriquillo-Cul-de-Sac Basin of Hispaniola}

The Enriquillo-Cul-de-Sac basin of southern Hispaniola is a 130-km-long east-west trending topographic depression that extends from Baie de Port-au-Prince, Haiti to Neiba Bay, Dominican Republic (Figure 1). During the higher sea level of the middle Holocene (6000 - 4800 BP), the Enriquillo Valley was a fully marine environment rimmed by fringing corals reefs that, together with the valley floor, formed an elongated embayment of the Caribbean Sea that closed on its western end near the present sill between Lake Enriquillo and Azuei (Figure 1). This embayment provided marine waters during the initial stages of the formation of the presently hypersaline Lake Enriquillo [6] [7]. Approximately 4300 to 4000 years ago, the embayment was isolated from the Caribbean Sea by a combination of tectonic uplift and sedimentation associated with the natural damning of the island's largest river system (Yacque Del Sur) and, as a result, Lake Enriquillo became progressively more hypersaline [6] [7].

Today, the Enriquillo Valley is bordered by WNE-ESE trending mountain that host interlocking spurs with intermittent streams, alluvial fans and inferred limestone systems. The valley floor is bisected by the EnriquilloPlantain Garden Fault Zone (EPGFZ), a left-lateral strike-slip fault system that extends from central Jamaica to the south-central section of Hispaniola (Figure 1). The EPGFZ crosses from east to west through Lake Enriquillo, sub-parallel to Isla Cabritos, and through the extreme southern end of Lake Azuei (Figure 1) [6] [8]. In addition to Lake Enriquillo and Azuei, two smaller lakes (Trou Caiman in Haiti, Laguna del Rincon in Dominican Republic) are present (Figure 1).

Since the hydrology and geology of Lake Enriquillo is more studied than Lake Azuei in Haiti and has experienced the most significant changes to its water levels, the lake represents a good starting place for understanding the relationships between lake levels and weather pattern changes across the region. Previous studies show that the lake is responsive to both short-term (seasonal/annual) and long-term (multi-decadal, 10 - 15 years) variations in weather and climatic patterns [1] [2] [9]. In 2006, another study [9] also presented evidence based on the reactivation of river channel correlating closely with a spike in Lake Enriquillo's water levels to suggest that hydraulic connectivity of rivers with the lake may also play a role in lake level rise, rather than climate changes alone.

\section{Methods for Testing the Weather/Climate Hypothesis}

\subsection{Determining Lake Elevation, Area and Volume Changes (1984-2013)}

During May 5-11, 2013, we collected $65 \mathrm{~km}$ of seismic reflection data using a portables ingle-channel CHIRP profiler. For our surveys, we mounted the CHIRP transducer along a steel pole and used a clamp system to attach the pole and transducer to a boat that travelled at $3-4$ knots. The chirp system produced pulses that have two different source frequencies: -a $3.5 \mathrm{KHz}$ center-frequency which imaged up to $30 \mathrm{~m}$ below the lake floor and a $200 \mathrm{kHz}$ center-frequency source that maps the lake's floor with sub-meter vertical resolution (Figure 2). As the 
system runs, it saves the seismic data in SEG-Y format and uses a non-differential GPS (mean accuracy $\pm 5 \mathrm{~m}$ ) to record each shot and receiver location. Each shot is produced roughly 30 seconds apart. We used the seismic images, together with Landsat data, to estimate lake level elevation and volume change with time.

These seismic images show no clear evidence for recent significant slumping. Since no major (>Mw 5) earthquakes have occurred within the area of Lake Enriquillo for at least the past 240 years [10], we suggest that it is unlikely that there has been significant recent changes to the lake's bathymetry due to ground motions that accompany major earthquakes. This implies that the lake's water level elevation changes are controlled primarily by lake water volume as opposed to tectonic or geomorphic changes in the lake bed. We use the Landsat images to outline the surface area of the lake per given time and conclude that each outlined lake surface area corresponds to a different lake level elevation. Since seismic data were also collected when the lake was at a higher elevation, the lake level elevation at low stands is represented by the mean depth from the 2013 water surface to the lake floor at the points where each lake level low stand (surface area polygon) intersect a known 2013 water depth.

We combine the seismic data and Landsat images with past bathymetric contour maps [1] to estimate the bathymetric profile across Lake Enriquillo. We update the contours [1] by first estimating the lake level elevation in 2003 and then by shifting the values of the contours by the mean lake level rise between 2003 and 2013. Finally, we use Sibson's natural neighbor interpolation method [11] to fill in depth values at the more under-sampled regions of the lake. In this interpolation method, the seismic and contour depths are used to create an initial tessellation of the lake's surface (i.e. a partitioning of the lake into Voronoi polygons that do not overlap) [11]. After initial tessellation, new Voronoi polygons are created for then on-sampled sections of the lake [11]. The depth value assigned to each new polygonis result of the integral of the weighted interpolation smoothing function (see [11]). Each weight is based on the degree of overlap between the new polygons and the Voronoi polygons from the initial tessellation. Ultimately, the Sibson's interpolation method favors smooth bathymetric profiles [11].

We then create a 2013 bathymetric map of Lake Enriquillo (Figure 2) and use it to calculate the lake's volume change with time. We begin to calculate lake volume by first partitioning each lake surface area polygon into smaller groups of $75 \mathrm{~m} \times 75 \mathrm{~m}$ bins. Afterwards, we multiply each binned area by its associated depth, and sum all bin values together to calculate total volume. We did not have the same type of bathymetric information for Lake Azuei. Instead, we make preliminary estimates of lake volume changes based on slope of the lake coastline during the past 10 years.

\subsection{Collecting Precipitation Data and Estimating Evaporation Rates}

To begin analyzing the effects of weather patterns on lake level change, we use meteorological data from the

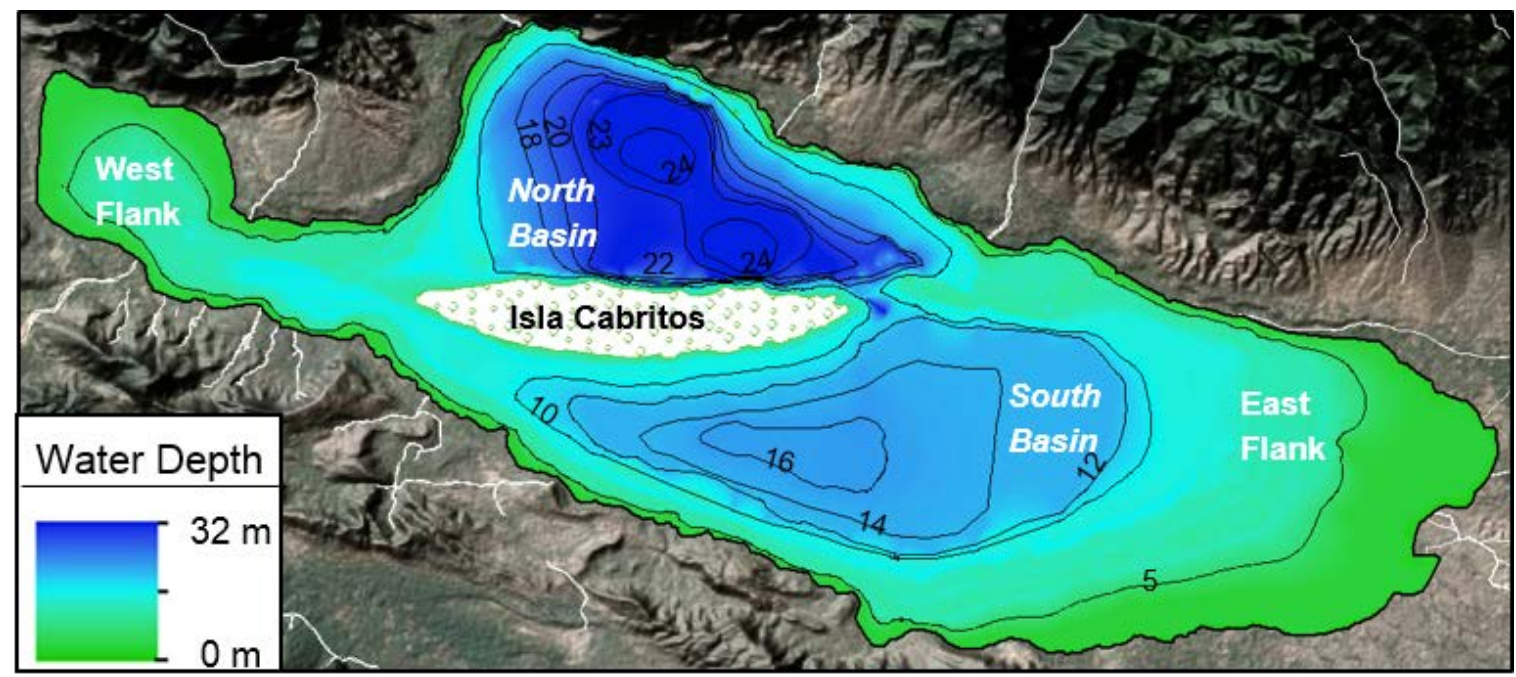

Figure 2. A bathymetry map that segments Lake Enriquillo into basins (north and south) and flanks (east and west) based on position and water depth. 
National Oceanic and Atmospheric Administration (NOAA) and the Jimani local weather station, located on the sill area separating Lake Enriquillo and Azuei (Figure 1), to account for both water sources (precipitation) and sinks (evaporation) in the region. Since neither station collects evaporation data at the site, we employ the Kohler-Nordenson-Fox (KNF) formula [12] to estimate the historical evaporation rates in the region.

Using root-mean-squared error, standard deviation and percent error analysis to gauge the relative error between empirical formula estimates for evaporation rates versus measured evaporation rate for 23 years of data, a recentstudy [13] confirmed that the KNF equation is a reliable empirical formula for estimating evaporation rates in a humid climate. In humid conditions, they showed that annual evaporation rate estimates from the KNF formula is within $4 \%$ of measured evaporation rates-as compared to the $11 \%, 26 \%, 21 \%$ and $26 \%$ errors by the Penman, Christiansen, Priestley-Taylor and Linacre methods respectively. The general formula (Equation (1)) for the KNF method is given below,

$$
E_{p a n}=\frac{\Delta R_{n}+\gamma_{p} E_{a}}{\Delta+\gamma_{p}}
$$

where $E_{p a n}$ is the estimation for the pan evaporation rates $\left(\mathrm{mm} \cdot \mathrm{d}^{-1}\right), \Delta$ is the gradient of the air temperature versus saturated vapor pressure curve $\left(\mathrm{kPa} /{ }^{\circ} \mathrm{C}\right), R_{n}$ is the net radiation $\left(\mathrm{mm} \cdot \mathrm{d}^{-1}\right), \gamma_{p}$ is the Kohner et al. (1955) derived psychometric constant $\left(0.001568 \mathrm{P}\right.$ in $\mathrm{kPa} /{ }^{\circ} \mathrm{C}$ where $\mathrm{P}$ is the atmospheric pressure in $\left.\mathrm{kPa}\right)$ and $E_{a}$ represents the aerodynamic function $\left(\mathrm{mm} \cdot \mathrm{d}^{-1}\right)$. Since these variables are not collected by NOAA or local weather stations, we re-write the KNF formula in terms of variables that are collected at the study location. To do that, we employ empirical formulas from several evaporation related studies [12] [14]-[17].

Using the KNF formula, as well as the auxiliary formulas found within the aforementioned studies [12] [14]-[17], we estimate that evaporation rates in the Enriquillo Valley ranged from 2.3 to $3 \mathrm{~mm} /$ day between 1970 and 2013. These values are within range of known pan evaporation rate estimates in Puerto Rico, the closest locality that has accessible evaporation data, as well as with remotely sensed derivations of evaporation rates over Hispaniola [18].

\subsection{Performing Correlation Analyses of Lake Levels and Weather Patterns}

We re-assess the weather hypothesis by quantifying the relationship between lake levels and weather patterns. To this end, we perform the Pearson product-moment correlation coefficient (PPMCC) test for the changes in lake levels versus the changes in weather patterns. Precipitation and evaporation rates were sampled on a monthly basis (1950-2013), while our sampling of the lake's water level elevation was limited by the number of available and cloudless Landsat images (1984-2013). Specifically, we resolve lake level elevation change for at least 2 - 7 months in 22 out of the 30 years since 1984 (i.e. we determined lake level elevation for an average of 4 months per year; the images used were taken at various times (wet and dry periods) throughout the year). We attempt to remove the sampling bias by first averaging the lake level elevation for each year, and then by finding the change rate for each successively sampled lake level elevation year (for example, good cloudless Landsat data is scarce between 1992 and 1996, therefore the 1992 lake elevation value would serve as the base year value when calculating the elevation change between 1992 and 1996). Afterwards, we down sampled our weather data to match the sampling resolution of our elevation data (i.e. the change in the 1996 weather data also uses 1992 as a base year). Lastly, we normalized the two data sets and used PPMCC formula to calculate the correlation coefficient between the lake level elevation and weather patterns change. Finally, we supplement the correlation data by comparing the lake's water level elevation change to the frequency and duration of storms in the drainage basin.

\section{Results}

\subsection{Basic Properties of the Lakes}

\subsubsection{Lake Bathymetry and Aerial Spreading Patterns}

Lake Enriquillo's surface area is controlled by the lake's bathymetry and regional topography. The lake is deepest in the north $(\sim 32 \mathrm{~m}$ in 2013) and south ( $18 \mathrm{~m}$ in 2013) basins and shallowest along the eastern and western lake flanks where $\sim 21 \%$ of the lake is below 4 meters (Figure 2). As of 2013, the lake had an average water depth of $11 \mathrm{~m}$. The east and west flanks of the lake exhibit a very gentle bathymetric gradient that ranges from 0 to 1.4 degrees. In contrast, the north and south basins, as well as the lake floor surrounding Isla Cabritos, a large 
geologic anticline [19], display steeper slopes that range from 4 to 9 degrees. As a result of the differences in bathymetric depth and slope, Lake Enriquillo typically experiences greater surface area growth on its western and eastern flanks than on the northern and southern flanks (Figure 2). From 2004 to 2013, measuring from the most protruding section of the lake flanks, the lake extended between 0.5 and $2 \mathrm{~km}$ north to south and between 6 and $8 \mathrm{~km}$ east to west.

\subsubsection{Lake Bathymetry and Aerial Spreading Patterns}

From 1984 to 2013, Lake Enriquillo's water level has ranged from 54 to 41 mbsl with a mean elevation of 50 mbsl (Figure 3). The lake's water level elevation was lowest in 2004 (54 mbsl) and highest in 2013 (41 mbsl). From 1984 to 1997, water levels generally drop from 49 to 51 mbsl respectively. Afterwards, we see a three year period of inter-annual to biennial lake level fluctuations ranging from 52 to $49 \mathrm{mbsl}$. This three year period is highlighted by the 1998 lake level rise which, incidentally, captures the range for the period. From 2000 to 2004, the lake level (again) generally dropped from $49 \mathrm{mbsl}$ to its lowest level, $54 \mathrm{mbsl}$. Finally, the 2005 to 2013 period is highlighted by a sustained $10 \mathrm{~m}$ rise (from 51 to $41 \mathrm{mbsl}$ ). We refer to the 2005 to 2013 increase in water level elevation as "recent lake level rise".

Lake Enriquillo's water volume and area changes mimic its elevation changes. The area curve shows predominant decreases from 1984 to 1997, then a relatively significant increase in area (in 1998) that is sustained until 2002. Afterwards, lake level generally falls until 2005. Lake area more than doubled from 2005 to 2013 , increasing from $162.3 \mathrm{~km}^{2}$ to $352 \mathrm{~km}^{2}$ (Figure 4). Lake volume shows the same general trend (Figure 4).

Lake Azuei's area ranged from 112 to $121 \mathrm{~km}^{2}$ between 1984 to 2006 and experienced several relatively minor $\left( \pm 4 \mathrm{~km}^{2} / \mathrm{yr}\right)$ fluctuations throughout that period (Figure 5). From 2006 to 2012, the lake grew from $121 \mathrm{~km}^{2}$ to $137 \mathrm{~km}^{2}$. The range and standard deviation of Lake Azuei's areal coverage is $25 \mathrm{~km}^{2}$ and 5.6 compared to Lake Enriquillo's values of $189 \mathrm{~km}^{2}$ and 5.5 respectively.

\subsection{Core and Correlation Analysis of Climate-Driven Lake-Level Change}

We collected three $25 \mathrm{~cm}$ cores within Lake Enriquillo in May, 2013. Foraminiferal biostratigraphy coupled

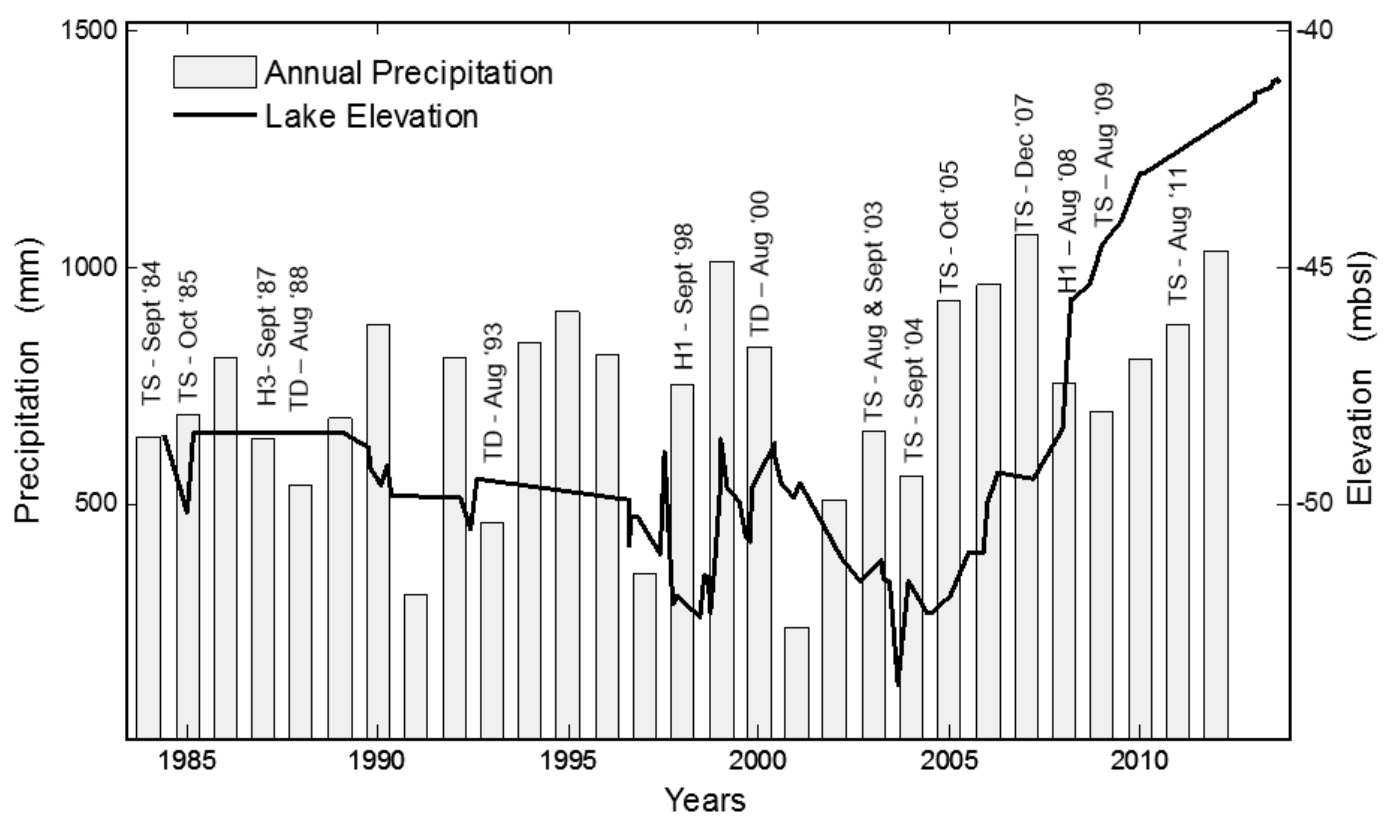

Figure 3. Graph shows the relationship between Lake Enriquillo's water level elevation, the annual precipitation rates from collected at the Jimani local weather station and timing of storms (tropical depression or greater) in the valley. Correlation analysis shows that a weak correlation exist between the two variables; TD stands for tropical depression, TS for tropical storm, H\# stands for the hurricane with the \# referring to the category of said hurricane. Lake Enriquillo's water levels tend to rise after the passage of storm events. 


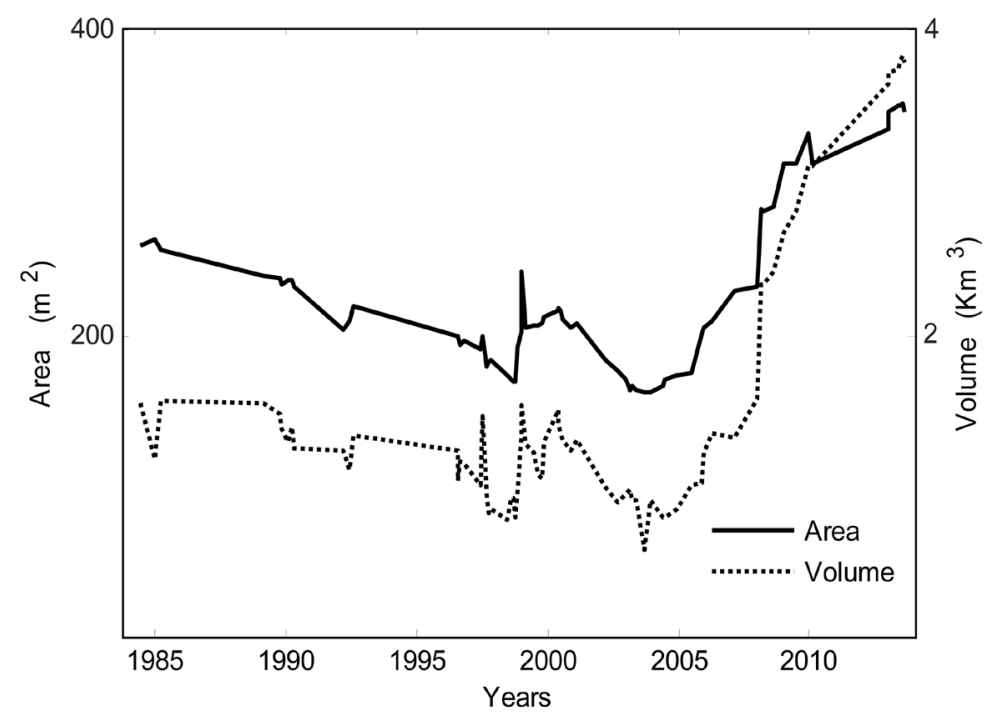

Figure 4. Graph of Lake Enriquillo's water area and volume history with time; it shows an unprecedented continuous growth in the lake's water area and volume since 2005.

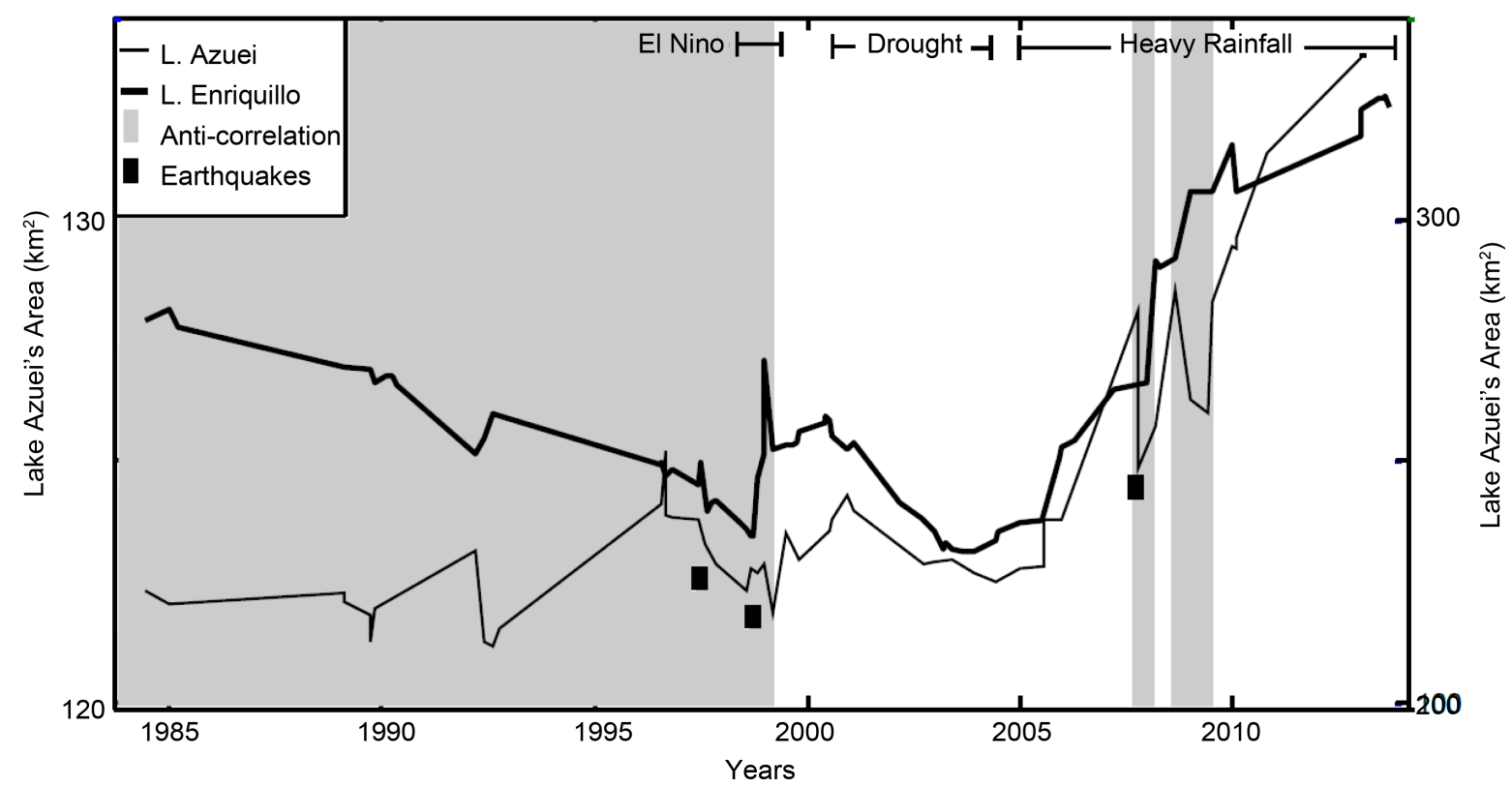

Figure 5. Graph highlights periods of correlation and anti-correlation between the Lake Enriquillo and Lake Azuei's areal change history with time. From this relationship we hypothesize that short-period of anti-correlation represent potential times when the lakes may have been in hydraulic communication. The graph also indicates significant changes in weather patterns as well as the timing of earthquakes in the valley.

with the X-ray fluorescence elemental analyses reveal a high salinity zone between $\sim 5-10 \mathrm{~cm}$ and low salinity zones between $\sim 0-5 \mathrm{~cm}$ and $\sim 10-20 \mathrm{~cm}$. The high salinity zones, represented by an abundance of Miliolid benthic foraminifers and increased $\mathrm{wt} \%$ of trace elements $\mathrm{Ca}$ and $\mathrm{Sr}$, are interpreted as dry evaporative periods. The low salinity zones, represented by an abundance of Ammonia tepida and Brizalina benthic foraminifers as well as the relative increases in the $\mathrm{wt} \%$ of $\mathrm{Si}$ and $\mathrm{Al}$ and the ppm concentrations of $\mathrm{Cr}$ and $\mathrm{Ni}$, are interpreted to be derived from terrigenous sources and transported to the lake during wetter periods. Together, the wet and dry periods represented in the cores indicate that Lake Enriquillo sediments record changing weather patterns. However, we are not able to provide age dates or sedimentation rates for these zones since short-lived radioisotopes 
were barely detectable within the cores. Instead, we rely on correlation analysis to further understand the timing relationship between lake levels and precipitation change in the region.

A weak correlation (0.20) exists between the change in Lake Enriquillo's water level elevation and the change in precipitation rates across the region (1984 to 2013). When the correlation test is performed for the 2005 to 2013 period, we see a moderately positive $(0.50)$ correlation. However, when we consider the effects of evaporation on the lake's water budget, the correlation $\mathrm{r}^{2}$ values reduce to 0.12 and to -0.37 for the 1984 to 2013 and 2005 to 2013 period respectively.

For Lake Azuei, we observe the same poor correlation value (0.08) between the lake's areal change and precipitation rates for the periods 1984 to 2013 and 2005 to 2013. When evaporation rates are accounted for, the correlation $\mathrm{r}^{2}$ value jumpsto 0.45 for the entire period and to 0.97 for the $2005-2012$ period.

\subsection{Storm Effects on Precipitation}

Since 1984, a total of 15 storms (tropical depression or larger) have tracked directly over Hispaniola (Figure 3). Years with storms across Hispaniola tend to have, on average, a $19 \mathrm{~cm}$ increase in precipitation rates [9]; however no such trend is found across the Enriquillo Valley basin. Instead, the mean precipitation rate for the 15 years with a storm was lower $(717 \mathrm{~mm} / \mathrm{yr})$ than the 15 years without a storm $(723 \mathrm{~mm} / \mathrm{yr})$. The $2005-2013$ period accounted for 5 of the 15 storms and records the highest mean lake level elevation and precipitation rate for any consecutive eight year period (45 mbsl and $892 \mathrm{~mm} / \mathrm{yr}$ ). Before that (1984-2004) there were 10 storms and the mean lake level elevation and precipitation rate was $50 \mathrm{mbsl}$ and $644 \mathrm{~mm} / \mathrm{yr}$ respectively (Figure 3). The mean precipitation rate for any consecutive eight year period (before 2005 to 2013) was $700 \mathrm{~mm} / \mathrm{yr}$.

Of the total 15 storms, 7 of them have tracked within a $100 \mathrm{~km}$ radius of Lake Enriquillo and Azuei (years1987, 1993, 1998, 2003, 2005, 2007, 2008). These storm years experienced a mean precipitation rate of 752 $\mathrm{mm} / \mathrm{yr}-29 \mathrm{~mm} / \mathrm{yr}$ higher than the mean precipitation rate for all the 15 storms that have tracked over the island, thereby suggesting that storm pathways across the country are important factors to consider when assessing the impact of storms on precipitation rates in the valley. Since 2005, the three years in which the storms tracked within a $100 \mathrm{~km}$ radius of the lake have had mean precipitation rate of $919 \mathrm{~mm} / \mathrm{yr}$ while storm years before 2005 experience a mean precipitation rate of $652 \mathrm{~mm} / \mathrm{yr}$. At least 9 out of the total 15 storms immediately precede increases in Lake Enriquillo's water level while at least 7 out of the 15 storms have immediately preceded short spikes in Lake Azuei's water levels. This preliminary result suggests the frequency of large storms tracking over the site plays an important role in lake level change.

Hurricanes Georges (1998), Jeanne (2004) and Alpha (2005) are examples of storms that have had significant impact on the hydrologic and geomorphologic landscape within the Enriquillo Valley i.e. lake level rises and widespread landslides and flooding in the valley (taken from NOAA Storm Reports between1984-2014). Hurricane Georges (September 1998) delivered over $900 \mathrm{~mm}$ of rain. Following the passage of Hurricane Georges, Lake Enriquillo rose approximately $2.5 \mathrm{~m}$ before the first sign of any lake level drop almost three months later-January 1999. On the other hand, Lake Azuei's area fell by $0.24 \mathrm{~km}^{2}$ between August and October 1998 but rose by $0.37 \mathrm{~km}^{2}$ between October and December 1998. Hurricane Jeanne (September 2004) lingered over the country for the longest time of any storm within the last 30 years (6 hours) and supplied over $300 \mathrm{~mm}$ of rain. Even though the storm tracked $\sim 145 \mathrm{~km}$ northeast along strike of the drainage basin, the storm was partly responsible for a $\sim 1 \mathrm{~m}$ rise in Lake Enriquillo's water level and a $0.5 \mathrm{~km}^{2}$ (at most) increase in Lake Azuei's area. Hurricane Alpha (October 2005) is the only storm to have tracked directly over Lake Enriquillo. The lake rose $\sim 0.5$ $\mathrm{m}$ between the passage of Alpha in September and January 2005. Clearer images are required to decipher Alpha's effect on Lake Azuei's areal coverage.

\subsection{Water Budget Contributions from the Drainage Basin}

If we limit the lake's water budget to the effects of direct precipitation (including rain from storms) and evaporation, we are able to calculate the yearly volume of water entering the lake via water transportation methods that exist in the land area of the drainage basin (rivers, ground water flow etc). The results show that the mean volume of water entering Lake Enriquillo, from the drainage basin, has increased by $0.38 \mathrm{~km}^{3} / \mathrm{yr}$ since 2005 . Between the 1985 to 2004 period, the lake required an average of $0.02 \mathrm{~km}^{3} / \mathrm{yr}$ volume input from the drainage basin compared to a $0.4 \mathrm{~km}^{3} / \mathrm{yr}$ between 2005 and 2013 (Figure 6). The years 2008, 2009 and 2012 require notably high volumes of water from the drainage basin $\left(1 \mathrm{~km}^{3}, 0.6 \mathrm{~km}^{3}\right.$ and $0.5 \mathrm{~km}^{3}$ respectively). 


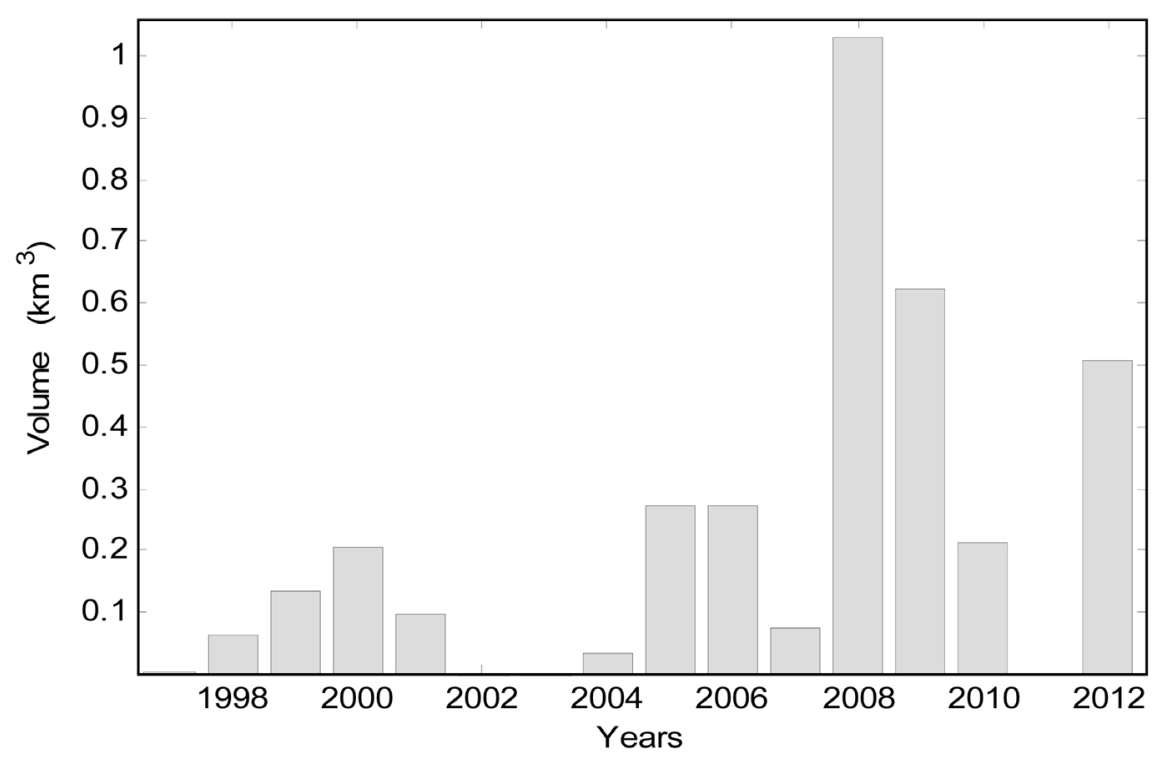

Figure 6. Bar graph shows the estimated annual volume of water entering Lake Enriquillo via non-direct means (i.e. all methods of water transportation except for direct precipitation of water into the lake). The volumes were calculated by subtracting the net direct input the lake (direct precipitation minus evaporation volumes) from the calculated yearly changes in volume; 2008-2012 require very high values of water in order to explain the changes in volume in Lake Enriquillo.

\section{Testing the Hydraulic Connectivity Hypothesis}

Though there have been contemporary (1984 to 2013) rises in the Lake Enriquillo's water levels following 9 out of 15 of the storms, the weak correlation between lake levels and precipitation and the notably high volumes of water required from the drainage basin to fill the lake in the latter years $(2008,2009$ and 2012) imply that changes in water supply from the drainage basin is an important contributing factor in Lake Enriquillo's water levels. Therefore, changes in precipitation across the region combined with changes in the hydraulic connectivity across the valley can control Lake Enriquillo's elevation.

The hydraulic connectivity hypothesis questions if the large volumes of water-required for explaining the change in Lake Enriquillo's water volume between 2008 and 2012 - may be attributed to greater hydraulic connectivity between Lake Enriquillo and Lake Azuei, the Rio Yacque del Sur or the Caribbean Sea. We test Lake Enriquillo's potential hydraulic connection to Lake Azuei by examining the relationship between their relative surface area and volume. For the Rio Yacque Del Sur, we explore changes in the stream and irrigation network that might enhance potential flow into Lake Enriquillo. Finally, we use water salinity studies to briefly test if the Caribbean Sea plays a significant role in supplying water to the Lake Enriquillo.

\subsection{Surficial Stream-Lake Hydrologic Connectivity within the Enriquillo Valley}

The main water bodies in the Enriquillo Valley-Trou Caiman, Lake Azuei and Enriquillo, Rio Yacque Del Sur, Laguna del Rincon - display varying degrees of surficial hydrologic connectivity (Figure 1). These connections occur in the form of natural as well as man-made streams. For example, Trou Caiman hydrologically connects to Lake Azuei and the Caribbean Sea via a man-made canal dug during the 1920's (Figure 1 Box 1) whose bed widths widen or narrow, respectively, as the volume of water in Trou Caiman expands or contracts. Photographs (dated 7/20/2002 to 5/9/2008) show that the canal between Trou Caiman and the Caribbean Sea was perhaps not operational between 2002 and 2008, but that the same channel was functional before 2002 and between 2009 and 2013. In contrast, the canal leading towards Lake Azuei maintained water flow between 2002 and 2013 and had a bed width of 3.5 and $6 \mathrm{~m}$ in 2002 and 2013 respectively. Though we have not directly measured the depth of this canal, analysis of satellite images indicates that the channel is likely relatively shallow $(0.3-0.5 \mathrm{~m})$. If the estimated depths are reasonable, we calculate (using the Manning's Equation) that the canal supplies between 
0.045 and $0.06 \mathrm{~km}^{3}$ of water per year to Lake Azuei.

Lake Enriquillo is fed by several streams that are either mostly confined to the mountains or the valley floors (Figure 1). Although karst emergent streams are a feature of the mountainous regions (Figure 1 Box 5), the majority of the channels in the mountains host ephemeral streams that direct water towards Lake Enriquillo during and after rainfall events. Watershed modelling (using ASTER DEMs) shows that, of these ephemeral streams, the stream identified by Box 4 of Figure 1 likely contributes the most volume of water to Lake Enriquillo; this is indicated by the number and length of water transport depression pathways that join the stream. Box 6 of Figure 1 identifies a section of Lake Enriquillo's most prominent and continuously flowing (largest volume flux and bed width-16 $\mathrm{m}$ in 2013) feeder stream. Photographs show that this stream was hydrologically connected to the irrigation system/the Rio Yacque del Sur (which feeds the irrigation system) prior to (latest 2003) the recent rise in Lake Enriquillo's water levels (Figure 1 Boxes 10, 11 and 12). By the latest 2010, the same stream had gained a second confluence with the irrigation system (Figure 1 Box 8; Figure 7(c)). The new confluence location indicates that the irrigation system/Rio Yacque del Sur has been contributing more water to the stream, and ultimately to Lake Enriquillo, since the latest 2010.
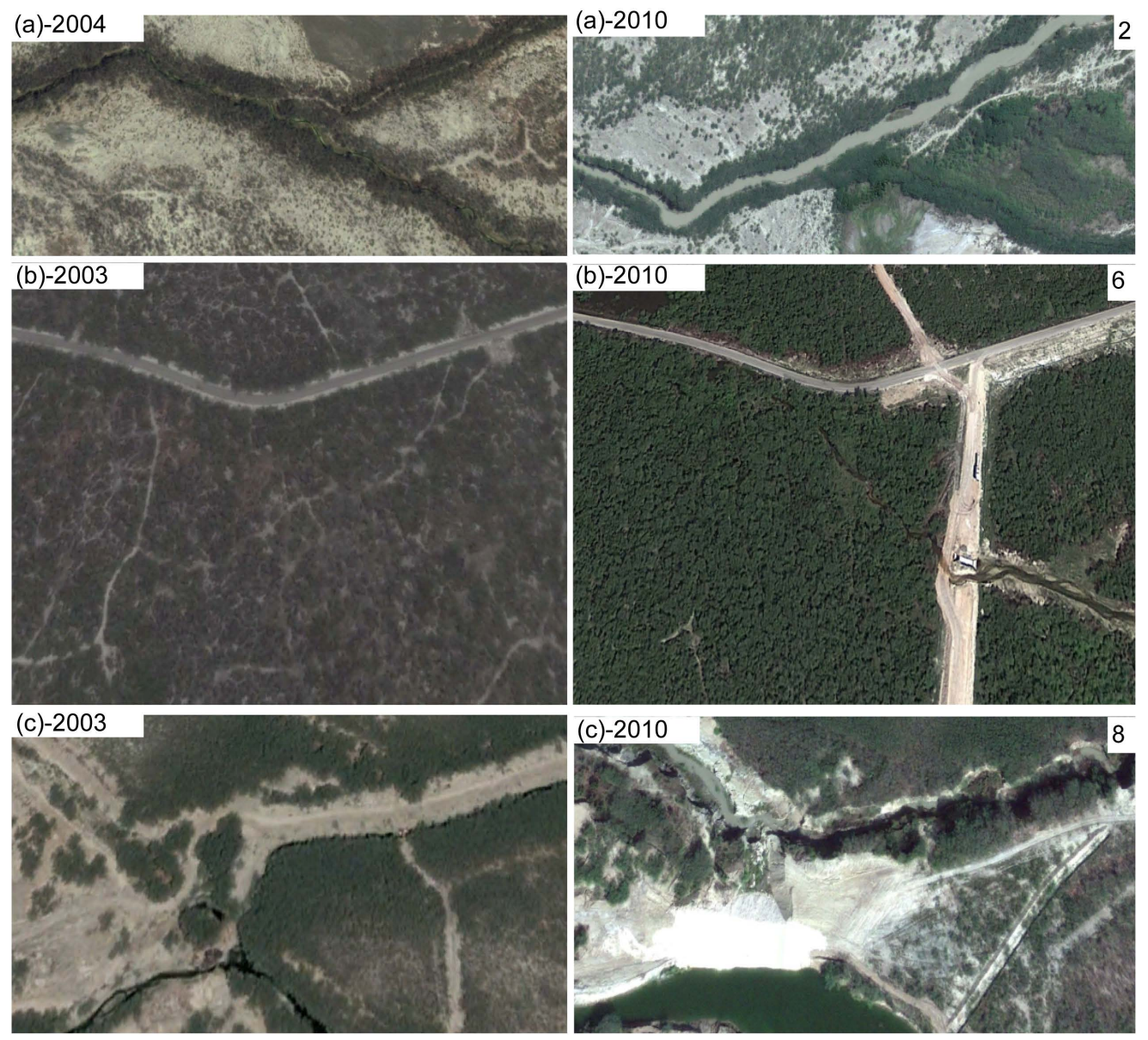

Figure 7. Photographs shows the hydrologic and geomorphic changes to three stream locations in the Enriquillo Valley. The alphanumeric text on the top left of the photographs (e.g. 7(a)-2004) refer to the figure identifier (7(a)) and the year the photograph was taken (2004); the number on the right of the photographs refer to the box location identifiers in Figure 1 (e.g. the number 2 on the top right of Figure 7(a) indicates that the adjacent photographs were taken at the location identified by Box 2 in Figure 1). Topographic maps dating back to 1984, as well as google earth images, show that there were no streams in the location photographed in 7a until around 2010; 7(b) shows the range of bed width for one of Lake Enriquillo's prominent feeder streams ( $2 \mathrm{~m}$ in 2003 and $16 \mathrm{~m}$ in 2010); 7(c) is the same stream as 7(b); the photograph from 7 (c) marks the location where stream $7(\mathrm{~b}) / 7$ (c) forms a second confluence with valley the irrigation system in 2010 . 
Local residents, as well as visiting scientists from the Instituo Nacional de Recursos Hidraulicos (INDRHI), note that Laguna del Rincon hydrologically connects to Lake Enriquillo during and after flooding events (Figure 1 Box 9). During heavy rainfalls or floods, water from the Yacque del Sur flows towards the Caribbean Sea and Lake Enriquillo (via the tributaries in the basin, via overland flow and via the irrigation system). Some of the water inevitably finds its way to Laguna del Rincon. The rainfalls, as well as the new supply of water from the Yacque del Sur, causes lake levels to rise at Laguna del Rincon. Once the lake overflows, the water makes its way towards other tributaries and the irrigation systems that discharge into Lake Enriquillo. This implies that more precipitation, combined with human-caused changes to regional hydrology in canals, contribute to the recent lake level rises.

\section{Hydrological and Geomorphic Changes to the Valley Streams}

Large rainfall events cause fluvial geomorphic changes in the valley. For example, Hurricane Georges (1998) reactivated an old river channel directly east of Lake Enriquillo [9]. This channel was partly (together with the hurricane itself) responsible for a $\sim 1.5 \mathrm{~m}$ rise (a month later) in Lake Enriquillo's water levels [9]. This is perhaps not an isolated case as images show that, following Hurricane Noel in 2007, new temporary rivers and ponds formed in and around the hinterlands of Laguna del Rincon. Satellite images also show that, following the passage of a low pressure rainfall system in 2004, the stream located at Box 3 of Figure 1 (also shown by Figure 8) was marked by wash over deposits and rill features that ultimately get eroded to form channels for several braided and intermittent streams that discharge into Lake Enriquillo (Figure 8). Given these examples, where changes in the geomorphology and hydrology of the valley closely correlate with storm events, we question whether the newly observed sinkhole (2010) between Lake Enriquillo and Azuei (Figure 1 Box 3) may be related to storm activity in the valley. Specifically, we hypothesize that increased water from storms should raise the water table and promote chemical weathering of the carbonates in the sub-surface-thereby creating favorable conditions sinkhole formation.

We also find that, on average, surface width increases in most to all of valley streams have coincided with increases in precipitation rates across the valley (2005-2013). Without current or historical flux and bed channel measurements, it remains unclear whether these changes are permanent (i.e. accompanied by incision and bed wall erosions). Given the $14-16 \mathrm{~m}$ increases in the surface width as well as new/more pronounced cut-banks (and meanders) seen in stream $7 \mathrm{a} / 7 \mathrm{c}$, we suggest that the stream has experienced widespread bed erosion. This type of stream erosion indicates that, at some points over the past 8 years, the stream's capacity has exceeded the sediment load in the channel [21]. Since a stream's capacity is dependent on its fluid discharge and velocity, we suggest that the stream's new connection with the Rio Yacque del Sur as well as the increase in storm activity in the region may have provided the necessary water to affect the flow regime of the stream. Perhaps even more interesting, but less known, is whether this new confluence location may be related to erosion caused by added storm waters in the region.

Using ASTER DEM watershed modelling where we assume that water travels down the path of steepest slope, we identify a favorable pathway for significant stream flow activity between Lake Enriquillo and Azuei. This predicted pathway is almost identical to the stream flow pathway of a new or reactivated stream (2010) that
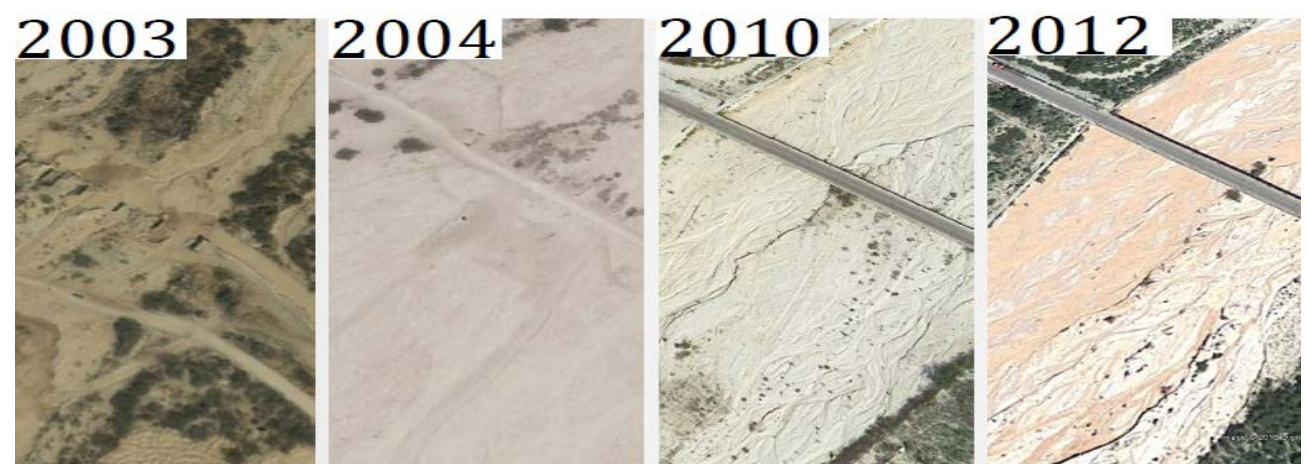

Figure 8. Photographs shows the initial change in the land before and after a strong storm event in 2004; it then shows what the continued geomorphic and hydrologic change that the area experienced in 2010 and 2012 . 
formed between Lake Enriquillo and Azuei (Figure 7(b) and Figure 1 Box 2). It is unclear why the stream was not present in any previous aerial photographs or topographic maps dating back to the 1980s. However, barring tectonic and other effects, riverbed incision along the hill slope is a competition between diffusive transport processes (soil creep, rain splash, bioturbation) and climatic conditions that provide the water for advectivetransport erosion along the hill slope [20]-[23]. Therefore, an increase in precipitation rates may have been an important contributing factor to the initial incision and channelization of the new stream. The recent rains likely generated improved water transportation within the new streams.

\subsection{Is Lake Enriquillo Hydrologically Connected to the Caribbean Sea?}

Historic salinities at Lake Enriquillo range from 22 to 104 ppt (Figure 9). From 2001 to 2003 salinity values were relatively high (81 ppt, 103 ppt, 104 ppt respectively), afterwards there was precipitous fall in 2004 (44 ppt) and a subsequent rise in 2005 (90 ppt) [1] [7] [9]. By 2013, the salinity values were at its lowest measured in the past thirty years, 22 ppt. Inter-annual variations of salinities are common [1] [7] [9], with the most drastic recent measurement coming from the year 1998 where salinities went down from $92 \mathrm{ppt}$ in July to $55 \mathrm{ppt}$ in October [9]. There are minor temporal and spatial variations in the salinity values for the north and south basins; however these variations are on the order of $\pm 2 \mathrm{ppt}$ [1] and are therefore ignored here. Higher salinity values generally correspond to lower lake level elevations and vice versa. Therefore, the fall from 90 to 22 ppt between 2005 and 2013 indicates that mostly fresh water has been introduced to the lake since 2005. This indicates that the Caribbean Sea is unlikely to be contributing large volumes of water to Lake Enriquillo.

\subsection{Is Lake Enriquillo Hydrologically Connected to Lake Azuei?}

We can make reasonable assessments about the lakes' potential hydraulic connectivity through detailed examinations of the relationship between their areas. In general, Lake Azuei experiences smaller surface area changes compared to Lake Enriquillo (Figure 5). The relatively smaller range in Lake Azuei's rise in lake level is likely due to the steep bathymetric and topographic gradient that exists on either side of the Lake Azuei's coastline (A. von Lignau, personal communication, June 17, 2014). This enables the lake to increase significantly in volume without expanding significantly in surface area. In contrast, larger fluctuations in Lake Enriquillo's areal

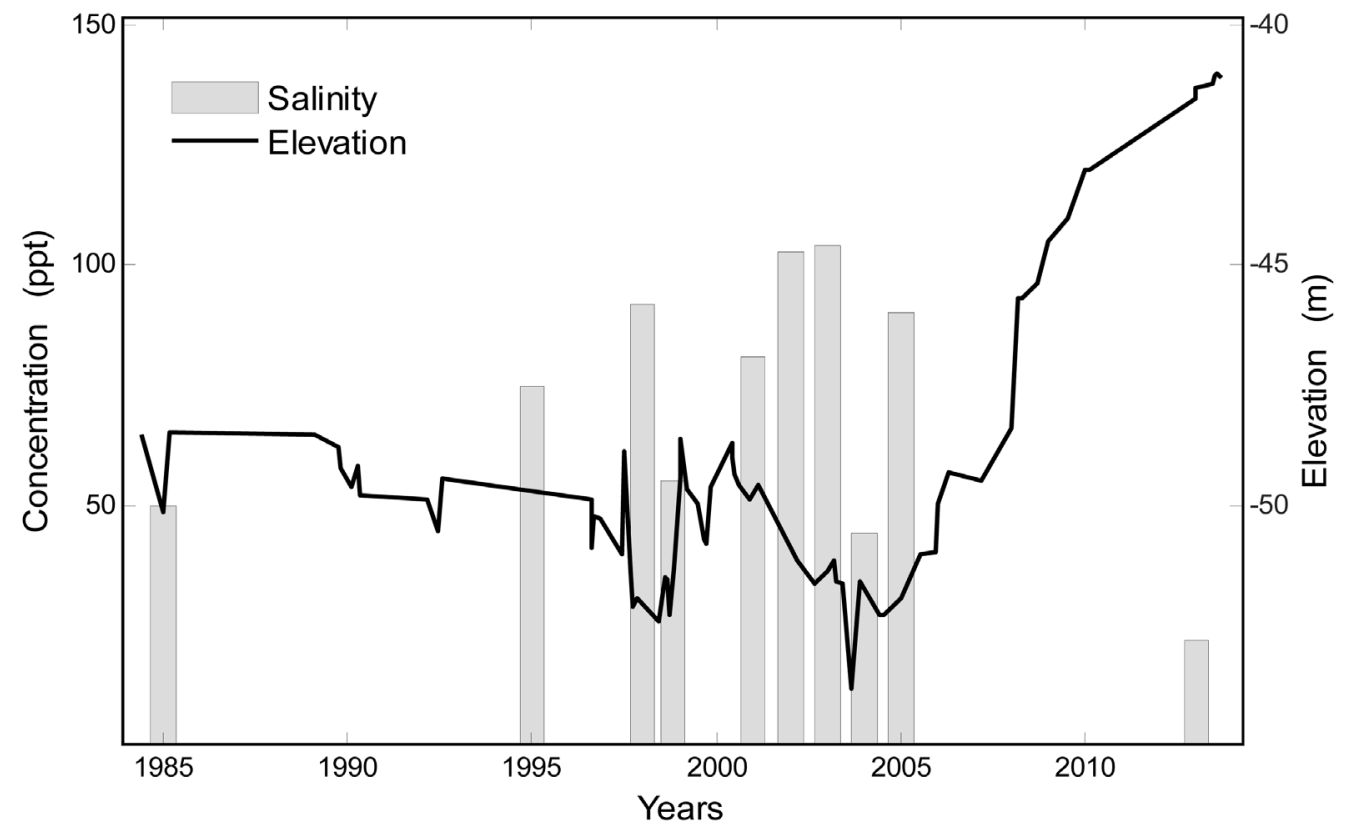

Figure 9. Graph compares Lake Enriquillo's water level history with the measured salinity values with time. The 2013 salinity measurements were collected using a salinity probe deployed off the side of the boat. Other measurements are taken from the literature [1] [6] [9]. Given the fall in salinity between 2005 and 2013, it is unlikely that the Caribbean Sea is playing a major role in Lake Enriquillo's lake level rises. 
coverage are likely due to the fact that Lake Enriquillo has a relatively gentler slope on its east and west flanks (Figure 1). Therefore, we interpret small changes to Lake Azuei's areal coverage as relatively large changes in volume and, at the same time, interpret large changes in Lake Enriquillo's surface area as moderate changes in its water volume.

Given that the lakes are only $5 \mathrm{~km}$ apart, we expect that both lakes will experience similar gains or losses to their water volumes and areas (i.e. a positive correlation between the changes in lake area). Without a catalyst that changes the fundamental relationships between the lakes' water budgets, we do not expect to see sustained/short periods of anti-correlation except if Lake Azuei acts as an upstream dam that opens (loses large volumes of water to Lake Enriquillo) and closes (retains its water) at different times as lake levels change (Figure 5; Figure 10). In such a system (Figure 10), the storage reservoir (upstream body of water, Lake Azuei) will lose water to the downstream outlet (downstream body of water, Lake Enriquillo) if the sluice gate is opened. The two water bodies will not be in hydraulic communication if the sluice gate is closed. Given that a $60 \mathrm{~m}$ hydraulic head exists between the lakes, we can consider the sluice gate in the dam system as an analogy for the critical water volume and pressure needed to promote sub-surface hydraulic communication between the lakes. The lakes would be in hydraulic communication only if there is sufficient water pressure to drive fluid flow through the joints in more permeable carbonates rocks between the lakes.

\section{Intermittent Hydraulic Connectivity between Lakes Azuei and Enriquillo?}

We begin our test of the lakes-dam analogy by identifying the anti-correlated and correlated periods in the lakes' relative area change with time. For 13 years (from 1984 until 1997), Lake Azuei experienced sustained periods (years) of lake level rises (1985-1989, 1990-1991, 1992-1996) (Figure 5); these periods are followed by very short periods (months) of lake level drops (in terms of area: $-0.6 \mathrm{~km}^{2}$ in $1984,-1.6 \mathrm{~km}^{2}$ in $1990,-3 \mathrm{~km}^{2}$ in 1992). During these same short periods, Lake Enriquillo experienced very abrupt lake level rises (in terms of area: $+4.5 \mathrm{~km}^{2}$ in $1984,+2.8 \mathrm{~km}^{2}$ in $1990,+15 \mathrm{~km}^{2}$ in 1992). The $1997-2013$ period shows a long-period of lake correlation interrupted by short period anti-correlations. Specifically, lake levels have mimicked each other for most of the 1997-2013 period, however Lake Enriquillo experiences three of its most areal dramatic growths
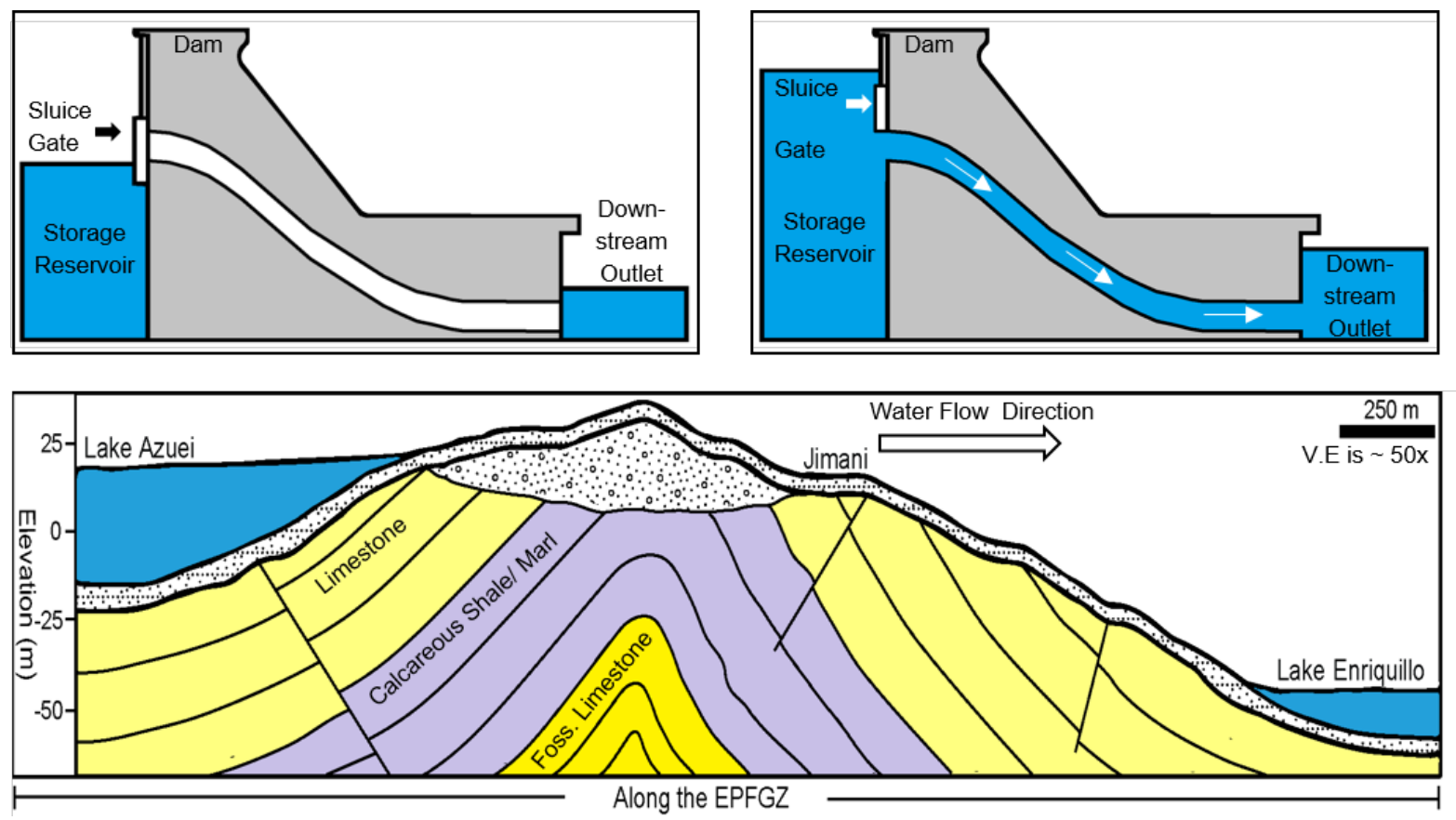

Figure 10. A cartoon illustration of how a hydrodam works (image adapted from Environment Canada in 2014) when the sluice gate is opened (a) and when it is closed (b); (c) shows the author's rendered scaled drawing of the possible subsurface geology between Lakes Enriquillo and Azuei (along the EPGFZ) based off government owned geological maps, stratigraphic columns and cross sections in the region. N.B Vertical exaggeration is $50 \times$ therefore dips on the layers in the figure are less steep than they appear. 
(1999, November 2007-February 2008 and August to December 2008: $+40 \mathrm{~km}^{2},+53 \mathrm{~km}^{2}$ and $+29 \mathrm{~km}^{2}$ respectively) directly following (or simultaneous with) significant lake level drops at Lake Azuei $\left(-2 \mathrm{~km}^{2},-6.5 \mathrm{~km}^{2}\right.$ and $-5.1 \mathrm{~km}^{2}$ respectively) (Figure 5).

The short periods of anti-correlated behavior between the lakes indicates that these years represent potential time periods when Lake Azuei may have contributed a substantial volume of water to Lake Enriquillo. We use elevation data along with calculated evaporation rates at Lake Azuei, to estimate (to first order) the volume of water loss (not including water evaporated from the lake) during short-periods of anti-correlation. Here, we present an example analysis of the most recent anti-correlation periods (i.e. the ones-2007-2008 and 2008that may be partly responsible for the changes in the lakes' water level elevation between 2005 and 2013).

The results suggest that Lake Azuei lost a total of at least $\sim 0.52$ to $0.77 \mathrm{~km}^{3}$ of water during the two anti-correlated periods-November 2007 to February 2008 and December 2008. In order to explain the change in Lake Enriquillo's water volume between September 2007 and December 2008, Lake Enriquillo needs $\sim 1.1 \mathrm{~km}^{3}$ of water entering the lake via water transportation methods that exist in the land area of the drainage basin. Since 2005, Lake Enriquillo has needed, on average, $0.4 \mathrm{~km}^{3}$ of water from the drainage basin to explain its changes in volume. If the average $\left(0.4 \mathrm{~km}^{3}\right)$ is subtracted from the total volume of water needed $\left(1.1 \mathrm{~km}^{3}\right)$, we note that the difference $\left(0.7 \mathrm{~km}^{3}\right)$ is in range for the estimated non-evaporitic volume of water loss from Lake Azuei. Additionally, we also note that the new sinkhole between the two lakes occurred around 2007, suggesting that there may have been fluids flowing within that region and also that ongoing dissolution of carbonate materials was likely occurring at the site. Given the information above, as well as carbonate geology, the existence of the EPGFZ (which provides a potential flow path parallel to the fault, see [24] [25]), the $60 \mathrm{~m}$ hydraulic head that exists between the two lakes, and the numerous wells and aquifers between the lakes, we suggest that Lake Azuei and Enriquillo experienced two periods of hydraulic connection between November 2007 and December 2008. More detailed analysis on Lake Enriquillo's and Azuei's water volume change with time is needed to analyze the potential hydraulic connection between the lakes before 2000 where the resolution of satellite images are insufficient to estimate the changes between lake levels during the examined periods.

\section{Discussion}

Like previous studies [2] [5], we have shown that changes to a wetter climate, including increases in the frequency and magnitude of storms in the Enriquillo Valley, has contributed to the recent lake level rise within Lake Enriquillo. Similar to study [1], we find that prolonged periods of lake level rises or falls are common within the lake. Our study improves upon past studies by also showing that these changes are insufficient to explain the recent lake levels rises and, that changes in hydraulic connectivity between Lake Enriquillo and Lake Azuei, runoff into Lake Enriquillo from the Rio Yacque Del Sur and other feeder rivers and ponds are also all potential contributors to the recent lake level rise of Lake Enriquillo. Here, we attempt to reconstruct the most likely sequence of events that preceded the increased hydraulic connectivity in the valley and the resulting rise in Lake Enriquillo's water level. The most active storm period (for any 8 year period of the historical record back to 1950) occurred between 2005 and 2013 (Figure 3). These storms are responsible for the $211 \mathrm{~mm} / \mathrm{yr}$ mean increase in the precipitation rates in the watersheds of the Lakes Enriquillo and Azuei experienced during this period (Figure 3). The timing and magnitude of these more frequent storms are ultimately controlled by sea surface temperature anomalies (SSTA) and wind strength and direction in the Atlantic Ocean [26] [27]. The relationship between storm frequency over Hispaniola and SSTA has been described by regional studies [9] [28]. These studies have supported the earlier works, see [26] [27] that show that strong westerly winds in the Antilles prohibit the formation of hurricanes and that the frequency of hurricanes over the Atlantic is reduced during El Nino periods when strong vertical shear winds dominate in the Atlantic Ocean. Our brief review of storm frequency in Southern Hispaniola over the past 63 years shows a similar trend with the past decade characterized by the departures of moderate El Ninos and the onset of La Nina periods that generally coincide with increased hurricane and storm activity.

The added storm water seems to (at times) act as hydrologic and geomorphic agents that cause increases in hydraulic connectivity, in terms of new connections or greater flux relationships, between Lake Enriquillo and the other water bodies within the valley. For example, the new stream seen in Figure 1 Box 2 currently directs water away from nearby hills and towards Lake Enriquillo. Without channelization, water from the hills would join the lower topography and do one of two main things: diffusively settle in naturally existing small rills that 
splay into different directions depending on the microtopography [22] or flow as sheets that tend to move more slowly (and be subjected to more surface evaporation and infiltration) than channelized unidirectional flow. In essence, without channelization water may tend to be otherwise directed (not necessarily towards Lake Enriquillo). The second example comes from stream $7 \mathrm{a} / \mathrm{c}$. In general, we hypothesize that Lake Enriquillo should, to a certain stream width to depth ratio threshold, see significant increases in current and future volume flux rate of water from stream $7 \mathrm{a} / \mathrm{c}$. This would allow more water to move from the source location (the hills in central Dominican Republic) as well as allow the stream to support more sediments and water during larger rainfall eventsa shallower stream may flood its banks more readily.

Both the weather and the changing hydraulic connectivity in the region combine to create tipping point conditions that increase the hydraulic connectivity between water bodies within the valley. Though these changes are poorly constrained, we can make first order attempts at identifying time periods when changing conditions may have resulted in valley-wide tipping points that lead to increased water flux into Lake Enriquillo through time. We suggest that many of the changes in hydraulic connectivity are a natural result of erosion and perhaps changes in subsurface flow, as we suggest between Lake Azuei and Lake Enriquillo. Nonetheless, man-made changes in water and dam control, as noted in section 5, are also likely factors that require much more thorough study.

Given the evidence for the temporary abandonment of the canal that leads from Trou Caiman to the Caribbean Sea, it appears that human monitoring of this canal could lower the water storage burden on Lake Azuei. For the irrigation dam systems, we can speculate that more water is supplied downstream (into Lake Enriquillo) during periods of significant rain. This speculation is based on the fact that dam workers will want toavoid upstream flooding and or water build-up behind the dam during significant rainfall. This could in theory add a positive feedback mechanism - the more it rains, the more humans and flood control canals release water directly into the lake either to avoid flooding of their crops or properties. Dam release methods could therefore act as another tipping point agent that can cause rapid lake level changes in Lake Enriquillo-such methods should be investigated further.

\section{Conclusions}

Our analysis indicates that changes to a wetter climate are not the only cause of the 2005-2013 societally disruptive 10 and $5 \mathrm{~m}$ rise in Lake Enriquillo's and Azuei's water levels respectively. We have used imagery from the period of 2000-2013 to show that Lake Enriquillo receives water from the Rio Yacque Del Sur via the Enriquillo Valley irrigation system that is used for sugarcane cultivation. Since the supply of the water in the irrigation system is dam controlled, it is likely that dam control methods play a role in lake levels. Additionally, we propose that Lake Enriquillo may have hydrologic connections to Lake Azuei in Haiti, as shown by significant drops in Lake Azuei correlating closely with rapid rises in Lake Enriquillo, and direct observations of sinkholes and new, perhaps intermittent stream flows between the lakes. However, it remains unclear how much water Lake Azuei supplies to Lake Enriquillo and what controls this hydrologic connection.

Future studies should seek to better constrain the lake's water budget. Those studies should collect and estimate current and historical flux measurements at the main rivers that discharge their water and sediment load in Lake Enriquillo. The studies should seek to understand Lake Azuei's water contribution to Lake Enriquillo by examining Lake Azuei's volume change rate with time, performing ground water flow tracer tests, and measuring surface flow between the lakes. Future studies should also consider testing if seismic activity along the EPFZ enhances or reduces hydrologic connections between Lakes Enriquillo and Azuei. Another area of future study is to investigate annual variations in dam discharge to see if there are consequent changes in the level of Lake Enriquillo. Finally, studies should use soil classification and infiltration studies to further constrain run-off and its relationship to Lake Enriquillo's water levels.

\section{Acknowledgements}

This material is based upon work supported by the National Science Foundation under Grant \# EAR-1042906 to UNAVCO. Financial support was also provided by grants from the Society of Exploration Geophysicists (SEG) "Geophysicists without Borders" program to Matthew Hornbach at Southern Methodist University and Paul Mann at University of Houston. We thank Alexander von Lignau, Javier Rodriguez, Alexander Holsteinsten, Freddy Estrella, Jose Pena, Cesar De Oleo, Manuel Rios, Yamil Rodriguez and La Autoridad Nacional de 
Asuntos Marítimos (ANAMAR), Dominican Republic, and the Haiti Bureau of Mining and Energy for their many contributions to the fieldwork on Lake Enriquillo and to our discussions. Special thanks to D. Gurung from Queens College who performed foraminiferal biostratigraphy and R. Bopp from Rensselaer Polytechnic Institute who conducted XRF analyses from cores from Lake Enriquillo.

\section{References}

[1] Buck, D.G., Brenner, M., Hodell, D.A., Curtis, J., Martin, J. and Pagini, M. (2005) Physical and Chemical Properties of Hypersaline Lago Enriquillo, Dominican Republic. Verhandlungen des Internationalen Verein Limnologie, 29, 1-7.

[2] Luna, E. and Poteau, D. (2011) Water Level Fluctuations of Lake Enriquillo and Lake Azuei in Response to Environmental Change. Master's Thesis, Cornell University, Ithaca.

[3] Daniel, T. and Lopez, E. (2013) Villages Slowly Vanish as Hispaniola Lakes Grow. Huffington Post. http://www.huffingtonpost.com/huff-wires/20120917/cb-dominican-republic-slow-motion-flood

[4] Comarazamy, D.E., González, J.E., Moshary, F. and Piasecki, M. (2015) On the Hydro-Meteorological Changes of a Tropical Water Basin in the Caribbean and Its Sensitivity to Mid-Term Changes in Regional Climate. Journal of Hydrometeorology, 16, 997-1013.

[5] Payano, R. and Medrano, O. (2012) Analisis de la Situacion Actual del Lago Enriquillo de La Republica Dominica. Master's Thesis, Colegio de Ingenieros de Caminos Canales y Puertos, Madrid.

[6] Mann, P., Taylor, F.W., Burke, K. and Kulstad, R. (1984) Subaerially Exposed Holocene Coral Reef, Enriquillo Valley, Dominican Republic. Geologic Society of America Bulletin, 95, 1084-1092. http://dx.doi.org/10.1130/0016-7606(1984)95<1084:SEHCRE>2.0.CO;2

[7] Taylor, F.W., Mann, P., Valastro, S. and Burke, K. (1985) Stratigraphy and Radiocarbon Chronology of a Subaerially Exposed Holocence Coral Reef, Dominican Republic. Journal of Geology, 93, 311-332. http://dx.doi.org/10.1086/628954

[8] Cowgill, E., Bernardin, T., Oskin, M.E., Bowles, C., Yikilmaz, B., Kreylos, O., Elliot, A., Bishop, S., Gold, R.D., Morelan, A., Bawden, G.W., Hamann, B. and Kellogg, L.H. (2012) Interactive Terrain Visualization Enables Virtual Fieldwork during Rapid Scientific Response to the 2010 Haiti Earthquake. Geosphere, 8, 787-804. http://dx.doi.org/10.1130/GES00687.1

[9] Greer, L. and Swart, P.K. (2006) Decadal Cyclicity of Regional Mid-Holocene Precipitation as Driven by Tropical Atlantic Sea Surface Temperatures: Evidence from Dominican Coral Proxies. Paleoceanography, 21, PA2020. http://dx.doi.org/10.1029/2005PA001166

[10] Bakun, W.H. (2012) Significant Earthquakes on the Enriquillo Fault System, Hispaniola, 1500-2010: Implications for Seismic Hazard. Bulletin of the Seismological Society of America, 102, 18-30. http://dx.doi.org/10.1785/0120110077

[11] Sibson, R. (1981) A Brief Description of Natural Neighbor Interpolation. In: Barnett, V., Ed., Interpreting Multivariate Data, John Wiley \& Sons, New York, 21-36.

[12] Kohler, M.A., Nordenson, T.J. and Fox, W.E. (1995) Evaporation from Pans and Lakes. US Department of Commerce and Research Paper 38.

[13] Irmak, S. and Haman, D. (2003) Evaluation of Five Methods for Estimating Class A Pan Evaporation in a Humid Climate. HortTechnology, 13, 500-508.

[14] Lamoreaux, W.W. (1962) Modem Evaporation Formulae Adapted to Computer Use. Monthly Weather Review, 90, 2628. http://dx.doi.org/10.1175/1520-0493(1962)090<0026:MEFATC >2.0.CO;2

[15] Jensen, M.E. (2010) Estimating Evaporation from Water Surfaces. Proceedings of the CSU/ARS Evapotranspiration Workshop, Fort Collins, 15 March 2010, 1-27.

[16] Samani, Z., Bawazir, A.S., Bleiweiss, M., Skaggs, R. and Vien, D. (2007) Estimating Daily Net Radiation over Vegetation Canopy through Remote Sensing and Climatic Data. Journal of Irrigation and Drainage Engineering, 4, 291 - 297.

[17] ASAE Standards.

[18] Harmsen, E.W., Mecikalski, J., Mercado, A. and Cruz, P.T. (2010) Estimating Evapotranspiration in the Caribbean Region Using Satellite Remote Sensing. Proceedings of the AWRA Summer Specialty Conference, Tropical Hydrology and Sustainable Water Resources in a Changing Climate, San Juan, 30 August-1 September 2010.

[19] Mann, P., Mclaughlin, P.P., Van Den Bold, W.A., Lawrence, S.R. and Lamar, M.E. (1999) Tectonic and Eustatic Controls on Neogene Evaporitic and Siliciclastic Deposition in the Enriquillo Basin, Dominican Republic. In: Mann, P., Ed., Sedimentary Basins of the World, Elsevier, Philadelphia, 287-342.

[20] Whipple, K.X. and Tucker, G.E. (2002) Implications of Sediment-Flux-Dependent River Incision Models for Land- 
scape Evolution. Journal of Geophysical Research, 107, 2039. http://dx.doi.org/10.1029/2000JB000044

[21] Montgomery, D.R. and Dietrich, W.E. (1992) Channel Initiation and the Problem of Landscape Scale. Science, 255, 826-830. http://dx.doi.org/10.1126/science.255.5046.826

[22] Dunne, T., Whipple, K.X. and Aubry, B.F. (2013) Microtopography of Hillslopes and Initiation of Channels by Horton Overland Flow. In: Costa, J.E., Miller, A.J., Potter, K.W. and Wilcock, P.R., Eds., Natural and Anthropogenic Influences in Fluvial Geomorphology, American Geophysical Union, Washington DC, 27-44.

[23] Ferrier, K.L., Huppert, K.L. and Perron, J.T. (2013) Climatic Control of Bedrock River Incision. Nature, 496, $206-209$. http://dx.doi.org/10.1038/nature11982

[24] Montgomery, D.R. and Manga, M. (2003) Streamflow and Water Well Responses to Earthquakes. Science, 300, $2047-$ 2049. http://dx.doi.org/10.1126/science.1082980

[25] Faulkner, D.R., Jackson, C.L., Lunn, R.J., Schlische, R.W., Shipton, Z.K., Wibberley, C.J. and Withjack, M.O. (2010) A Review of Recent Developments Concerning the Structure, Mechanics and Fluid Flow Properties of Fault Zones. Journal of Structural Geology, 32, 1557-1575. http://dx.doi.org/10.1016/j.jsg.2010.06.009

[26] Gray, W.M. (1984) Atlantic Seasonal Hurricane Frequency: Part I: El Nino and the 30 mb Quasi-Biennial Oscillation Influences. Monthly Weather Review, 112, 1649-1668. http://dx.doi.org/10.1175/1520-0493(1984)112<1649:ASHFPI $>2.0 . C O ; 2$

[27] Gray, W.M., Sheaffer, J.D. and Landsea, C.W. (1997) Climate Trends Associated with Multidecadal Variability of Atlantic Hurricane Activity. In: Diaz, H.F. and Pulwarty, R.S., Eds., Hurricanes: Climate and Socioeconomic Impacts, Springer-Verlag, New York, 15-53. http://dx.doi.org/10.1007/978-3-642-60672-4 2

[28] Nyberg, J., Malmgren, B., Winter, A., Jury, M., Kilbourne, K. and Quin, T. (2007) Low Atlantic Hurricane Activity in the 1970s and 1980s Compared to the Past 270 Years. Nature, 447, 697-701. http://dx.doi.org/10.1038/nature05895 